\title{
The American Society for Clinical Investigation, Inc. Fifty-Eighth Annual Meeting
}

\section{6}

MORNING PROGRAM

Monday, May 2, 1966

9:00 a.m. Pennsylvania Room, Haddon Hall

First Business Meeting

The President's Address: Dr. Donald W. Seldin

\section{SCIENTIFIC SESSION \#}

(The time for the presentation of each paper will be limited to 10 mimutes.)

Chairman: Dr. Donald W. Seldin

1. Role of Sympathetic Nervous System in Mediating Renal and Adrenocortical Secretory Responses to Upright Posture. R. D. Gordon, O. Kuchel, D. P. IsLAND, and G. W. Lidde,,* Nashville, Tenn.

2. Studies of Uterine Renin. P. Gorden, T. F. Ferris, and P. J. Mulrow,* New Haven, Conn.

3. Suppression of the Shunt Pathway in Primary Gout by Azathioprine. L. B. Sorensen, Chicago, Ill. (introduced by A. Kappas*).

4. Dissociation by Colchicine of Phagocytosis Per Se from Increased Oxygen Consumption in Human Leukocytes. S. E. Malawista and P. Bodel, New Haven, Conn. (introduced by E. Atkins*).

5. Mixed Cryoglobulins Associated with Purpura, Arthralgia, and Acute Renal Failure. M. Meltzer, E. C. Franklin,* K. Elias, R. T. McCluskey, N. CoOper, and P. Miescher,* New York, N. Y.

\# The President is most grateful to the Chairmen of the Sectional Programs, whose advice and guidance were of great value in the selection of this program.

* In abstracts submitted to the ASCI, active member of ASCI.

$\dagger$ In abstracts submitted to the ASCI, emeritus member of ASCI.

$\ddagger$ In abstracts submitted to the AFCR, member of AFCR.

$\S$ In abstracts submitted to the AFCR, senior member of AFCR.
6. Intestinal Lymphangiectasia: A Protein-losing Enteropathy with Hypogammaglobulinemia Lymphocytopenia and Impaired Homograft Rejection. W. Strober, R. D. Wochner, P. P. Carbone, and T. A. Waldmann,* Bethesda, Md.

7. Studies of Intestinal Microvilli: Intrinsic Factormediated Attachment of Vitamin $B_{12}$ to Brush Borders and Microvillous Membranes. R. M. Donaldson, JR., I. L. Mackenzie, and J. S. Trier, Madison, Wis.

8. Demonstration That 2-Monoglycerides Are Incorporated Intact into Human Lymph Triglycerides. H. J. Kayden, J. R. Senior, and F. H. Mattson, New York, N. Y. (introduced by C. E. Kossman †).

9. Cell Lipid Content and Cell Number in Obese and Nonobese Human Adipose Tissue. J. Hirsch,* J. L. Knittle, and L. B. Salans, New York, N. Y.

10. Dynamic Exchange of Intact Hemoglobin Hemes. H. F. Bunn and J. H. JANd,,* Boston, Mass.

11. Platelet Thrombosthenin-Function and Subcellular Localization. R. L. NACHMAN and A. J. MARCUS,* New York, N. Y.

12. Role of Excess $\alpha$-Chain Synthesis in the Pathogenesis of $\beta$ Thalassemia. A. BANK and P. A. MARKs,* New York, N. Y.

13. Deletion of the Cholesterol Negative Feedback System in Precancerous Liver. M. D. Siperstein,* Dallas, Texas.

\section{AFTERNOON PROGRAM}

\section{2:00 p.m. Pennsylvania Room, Haddon Hall}

Second Business Meeting

\section{SCIENTIFIC SESSION}

\section{Chairman: Dr. John W. Harris}

14. Vasodepressor and Antihypertensive Prostaglandins of PGE Type with Emphasis on the Identification of

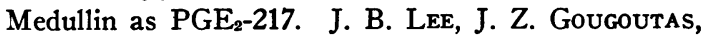
B. H. Takman, E. G. Daniels, M. F. Grostic, J. E. Pike, J. W. Hinman, and E. E. Muirhead, $\dagger$ Worces- 
ter and Cambridge, Mass., Kalamazoo, Mich., and Memphis, Tenn.

15. Quantitation of Mitral Regurgitation with ${ }^{189}$ Xenon. J. D. Morch, H. J. Smith, and M. McGregor,* Montreal, Canada.

16. Left Ventricular Emptying in Outflow Tract Obstruction. J. M. CRILEY, W. S. Wilson, and R. S. Ross,* Baltimore, Md.

17. Some Characteristics of the Renal Nuclear Receptors for Aldosterone. D. D. Fanestil and I. S. EdelMAN,* San Francisco, Calif.

18. Evidence for an Acidification Defect of the Proximal Renal Tubule in Experimental and Clinical Renal Disease. R. C. Morris, San Francisco, Calif. (introduced by L. H. Smith, Jr.*).

19. The Acid-Base Behavior of Separated Renal Tubules. A. Struyvenberg, R. B. I. Morrison, and A. S. Relman,* Boston, Mass.

20. Glucagon Regulation in Normal and Obese Diabetic Subjects. D. S. SCHALCH, Rochester, N. Y. (introduced by J. R. JAENIKE*).
21. Effects of Oral Phosphate Supplements in Demineralizing Disorders of Bone. R. S. Goldsmith and S. H. IngBar,* Boston, Mass.

22. A Common Mechanism for the Fungicidal and Nephrotoxic Effects of Amphotericin B. G. WeIssmann,* M. Pras, and R. Hirschhorn, New York, N. Y.

23. Decreased Bactericidal Activity of Polymorphonuclear Leukocytes in Children with Chronic Granulomatous Disease. P. G. QUIE, J. G. White, B. Holmes, and R. A. Good,* Minneapolis, Minn.

24. In Vivo Transmission of Antibiotic Resistance between Strains of Staphylococcus aureus. S. I. Morse * and R. P. Novick, New York, N. Y.

25. Human Cholesterol Synthesis Is Regulated by Bile Acids. S. M. Grundy, A. F. Hofmann, J. Davignon, and E. H. Ahrens, Jr., † New York, N. Y.

26. The Biosynthetic Origin of Serum Cholesterol in the Monkey. J. D. Wilson * and J. M. Dietschy, Dallas, Texas.

\section{PROGRAMS OF THE SECTIONAL MEETINGS HELD JOINTLY WITH THE AMERICAN FEDERATION FOR CLINICAL RESEARCH}

\section{CARDIOVASCULAR}

Sunday, May 1, 1966

\author{
Afternoon Session \\ 2:30 p.m. Pennsylvania Room II, \\ Haddon Hall
}

Chairman: Dr. Richard S. Ross

1. An Evaluation of Post Transfusion Hepatitis and Post Pump Syndrome after the Use of Extracorporeal Circulation. R. Rosenblum $\ddagger$ and W. J. Heidenberg, New York, N. Y. AFCR

2. Cardiac Output and Organ Blood Flow of the Fetus In Utero. A. M. Rudolph * and M. HeymanN, New York, N. Y. ASCI

3. The Effects of Isoproterenol on Dispersed Beating Heart Cells in Tissue Culture. D. C. Harrison, $\ddagger$ R. E. Kleiger, and T. C. Merigan, $\$$ Palo Alto, Calif. AFCR

4. Improvement in Cardiac Efficiency of Catecholamineinduced Positive Inotropy by Partial Beta-Adrenergic Blockade. C. A. SANDERS, R. K. MYler, and H. B. Corning, Boston, Mass. (introduced by S. M. Krane *). ASCI

5. The Positive Inotropic Effect of Acetylcholine on Ventricular Myocardium and Its Relation to Cardiac Norepinephrine Stores. R. A. Buccino, E. H. SonNenblick, T. Cooper,* and E. Braunwald,* Bethesda, Md., and St. Louis, Mo. ASCI

6. Myocardial Hypoxia in Patients with Ischemic Heart Disease. W. A. NeIll, $\ddagger$ Portland, Ore. AFCR
7. Effects of Changes in Ventricular Rate on the Coronary Hemodynamics in the Unanesthetized Dog. B. PitT and D. E. GregG, Washington, D. C. (introduced by A. Leon $\ddagger$ ). AFCR

8. The Mechanism Normally Limiting the Maximal Cardiac Output. S. E. Epstein, B. F. Robinson, R. L. Kahler, $\ddagger$ and E. Braunwald, $\ddagger$ Bethesda, Md. AFCR

9. Digoxin-specific Antibodies. V. P. Butler, JR., B. F. Erlanger, and J. P. Chen, New York, N. Y. (introduced by C. Ragan $\dagger$ ). ASCI

\section{DERMATOLOGY}

$$
\text { Sunday, May 1, } 1966
$$

\section{Afternoon Session}

\section{2:30 p.m. Terrace Room, Colton Manor Chairman: Dr. Aaron B. Lerner}

1. Some Submicroscopic Characteristics of Epithelial Regeneration in Experimental Human Skin Wounds. G. F. Odland and R. Ross, Seattle, Wash. (introduced by R. G. Petersdorf*). ASCI

2. Cellular Sites of RNA and Protein Synthesis in $\mathrm{Hu}-$ man Epidermis. K. Funuyama $\ddagger$ and W. L. Epstein, $\$$ San. Francisco, Calif. AFCR

3. Collagen Content, Solubility, and Cross-Linking in Human Dermis. E. HARris, JR., and A. SJoerdsma,* Bethesda, Md. ASCI

4. Bradykinin Release by Mediators of Inflammation. H. Zachariae, W. Pettinger, $\ddagger$ and J. A. OAtes $;$ Nashville, Tenn. AFCR 
5. Genetic Aspects of Autoimmune Disease in NZB/ NZW Mice. I. M. Braverman and J. Marino, New Haven, Conn. (introduced by A. V. N. Goodyer $\dagger$ ). ASCI

6. Diagnostic Paraprotein in Lichen Myxedematosus (L.M.). H. H. Fudenberg, $\ddagger$ K. James, W. L. Epstein, $\$$ and J. Shuster, San Francisco, Calif. AFCR

7. Cutaneous Depigmentation. M. A. Pathak, $\ddagger$ E. Frank, G. Szabo, and T. B. Fitzpatrick, $\S$ Boston, Mass. AFCR

8. Effect of Chlormadinone Acetate on Sebum Production and Plasma Testosterone in Man. J. S. Strauss, $\ddagger$ P. E. Pochi, $\ddagger$ E. Forchielli, and R. I. Dorfman, Boston, Mass., and Palo Alto, Calif. AFCR

9. Radioautography of C 14 Norepinephrine in Atopic Dermatitis. L. Solomon and N. NAdLER, Montreal, Canada (introduced by J. L. Brandt §). AFCR

\section{ENDOCRINOLOGY}

Sunday, May 1, 1966

\section{Afternoon Session \\ 2:30 p.m. Carolina Room, Chalfonte \\ Chairman: Dr. Monte A. Greer}

1. The Relative Importance of Calcium and Phosphate in the Secretion of Parathyroid Hormone. L. M. Sherwood, G. P. Mayer, C. F. Ramberg, JR., D. S. Kronfeld, J. T. Potts, JR., and G. D. Aurbach,* Bethesda, Md., and Kennett Square, Pa. ASCI

2. Vasopressin Antibodies and a Sensitive Radioimmunoassay. J. Roth, L. A. Klein, and M. J. Petersen, Bethesda, Md. (introduced by J. E. Rall*). ASCI

3. Some Aspects of the Physiology of Human Luteinizing Hormone (HLH) as Determined by Radioimmunoassay. W. D. Odell and G. T. Ross, Bethesda, Md. (introduced by M. B. Lipsett*). ASCI

4. The Incidence of Primary Aldosteronism in Patients with "Essential" Hypertension. N. M. Kaplan, Dallas, Texas (introduced by R. H. Unger *). ASCI

5. 17-Hydroxylation Deficiency in Man. E. G. BigLIERI,* San Francisco, Calif. ASCI

6. An Effect of ACTH on the Late Steps of Corticosterone Biosynthesis and Its Dependence on Adrenal Protein Synthesis. R. L. NeY, $\ddagger$ R. N. Dexter, $\neq$ W. W. Davis, $\ddagger$ and L. Garren, $\ddagger$ Nashville, Tenn., and Bethesda, Md. AFCR

7. Binding of Thyrotrophin to Thyroid Slices: A Reversible Step in Hormone Action. I. Pastan, Bethesda, Md. (introduced by J. Robbins*). ASCI

8. On the Mode of Action of Thyroid Stimulators. J. M. McKenzIE,* Montreal, Canada. ASCI

9. Determination and Kinetic Significance of the Exchangeable Intracellular Thyroxine Pool in Man. J. H. Oppenheimer, G. Bernstein, J. Hasen, and C. H. Sutron, New York, N. Y. (introduced by L. Leiter $\dagger$ ). ASCI

\section{GASTROENTEROLOGY}

Sunday, May 1, 1966

\author{
Afternoon Session \\ 2:30 p.m. Rutland Room, Haddon Hall \\ Chairman: Dr. Cyrus E. Rubin
}

1. Jejunal Bile Salt Abnormalities in Malabsorption with Bacterial Stasis. I. H. Rosenberg, W. G. Hardison, and D. M. Bull, Boston, Mass. (introduced by C. S. Davidson §). AFCR

2. The Role of Bile Salts in the Renal Exretion of Bilirubin. J. SANDson * and M. FuloP, Bronx, N. Y. ASCI

3. S-Adenosylmethionine in the Liver after Portacaval Venous Anastomosis. R. J. Baldessarini and J. E. Fischer, Bethesda, Md., and Boston, Mass. (introduced by S. S. Kety $\dagger$ ). ASCI

4. Production of Chronic Hepatic Injury Following Viral Hepatitis in Partially Immune Dogs. D. J. Gocke, R. Preisig, T. O. Morris, S. Erlinger, and S. E. Bradley, New York, N. Y. (introduced by H. O. Wheeler §). AFCR

5. Studies on Intracerebral Toxicity of Ammonia $\left(\mathrm{NH}_{3}\right)$. S. Schenker, D. McCandless, E. Brophy, and M. Lewis, Dallas, Texas (introduced by B. Combes*). ASCI

6. Metabolism of Circulating Disaccharides in Man and the Rat. E. Weser and M. H. Sleisenger,* New York, N. Y. ASCI

7. Comparison of Electrolyte Transport in Relation to Intraluminal Concentrations in the Human Jejunum and Ileum. S. F. Phillips and W. H. J. Sum merskILL, Rochester, Minn. (introduced by C. F. Code $\dagger$ ). ASCI

8. Reduction of Esophageal Sphincter Strength in Subjects with Heartburn. C. E. POPE II, $\ddagger$ Seattle, Wash. AFCR

9. Transplacental Passage of Maternal $B_{12}$-blocking Antibody to Intrinsic Factor: A Possible "Temporary Pernicious Anemia." S. BAR-Shany and V. HerBERT, $\ddagger$ New York, N. Y. AFCR

\section{GENETICS}

Sunday, May 1, 1966

Afternoon Session

\section{2:30 p.m. Garden Room, Haddon Hall}

\section{Chairman: Dr. H. Neil Kirkman}

1. $\mathrm{Hb} \mathrm{C}_{\text {Georgetown }}$ First Abnormal Hemoglobin Due to Two Different Mutations in the Same Gene. P. S. Gerald* and C. E. Rath, Boston, Mass., and Washington, D. C. ASCI 
2. Hereditary Nonspherocytic Hemolytic Disease Associated with Altered Phospholipid Composition of the Erythrocytes. E. R. Jaffé,* E. L. Gottfried, and T. B. Bradley, JR., New York, N. Y. ASCI

3. Hereditary Deficiency of the Second Component of Complement in Man. F. S. Rosen, J. Kumate, M. R. Klemperer, and K. F. Austen,* Boston, Mass., and Mexico, D. F. ASCI

4. Sex Chromatin and the Cell Cycle. D. E. Comings, $\ddagger$ Seattle, Wash. AFCR

5. Studies of Individual RBC in G6PD-deficient Heterozygotes and Hemizygotes. J. C. GALL and C. J. BREwER, $\ddagger$ Ann Arbor and Northville, Mich. AFCR

6. Color-Vision Defects in Alcoholic Cirrhosis. P. J. Fialkow, $\ddagger$ H. C. Thuline, and L. F. Fenster, $\ddagger$ Seattle and Buckley, Wash. AFCR

7. Genetic Regulation of Apoferritin Synthesis in Rat Liver. Y. Yoshino, D. Schachter,* and J. Manis, New York, N. Y. ASCI

8. Ribosomal Turnover in Tissues of Fed, Fasted, and Tumor-bearing Rats. C. A. Hirsch and H. H. Hiatr,* Boston, Mass. ASCI

9. Protein Synthesis by Reticulocytes: Presence of a Subribosomal Pool of Stimulatory Nucleoprotein. N. S. Beard, S. Armentrout, and A. S. WeisBERGER, $\dagger$ Cleveland, Ohio. ASCI

\section{HEMATOLOGY}

Sunday, May 1, 1966

\section{Afternoon Session}

\section{2:30 p.m. Vernon Room, Haddon Hall}

Chairman: Dr. Hugh Chaplin, Jr.

1. Membrane Lipid Depletion during Cation Pumping: A Mechanism for the Genesis of Spheroidal Red Cells in Hereditary Spherocytosis (HS). H. S. JACOB, Boston, Mass. (introduced by F. Stohlman, Jr.*). ASCI

2. Alteration of Normal RBCs by -SH Compounds: Clue to the Intracorpuscular Abnormality in Paroxysmal Nocturnal Hemoglobinuria (PNH). H. E. KANN, JR., $\ddagger$ C. E. Mengel, $\ddagger$ and W. D. Meriwether, Columbus, Ohio. AFCR

3. Further Studies on the Hemolysis of Human Red Cells by Late-acting Complement Components. S. YACHNIN,* Chicago, I1l. ASCI

4. Interactions between Haptoglobin and Isolated $\alpha$ and $\beta$ Subunits of Human Hemoglobin. M. J. SmIth and W. S. BECK,* Boston, Mass. ASCI

5. Acetophenetidine Sensitivity. N. T. Shatid, $H$. Wyler, W. H. Hitzig, A. Dreiding, and A. Prader, Zurich, Switzerland (introduced by W. B. Castle $\ddagger$ ). AFCR
6. Human Platelet ATPase Activities: Relationship of Localization to Function. L. M. Aledort, S. B. Troup, and R. I. Weed,* Rochester, N. Y. ASCI

7. The Protein Requirement for Platelet Surface Reaction. M. F. Glynn, M. A. Packham, J. Hirsch, and J. F. Mustard,* Bethesda, Md., and Toronto, Canada. ASCI

8. Serum Muramidase and Granulocyte Turnover. M. E. FinK $\ddagger$ and S. C. FINCH, $\S$ New Haven, Conn. AFCR

9. Humoral Regulation of Neutrophil Release from Bone Marrow. D. R. Boggs, J. C. MARSh, and G. E. Cartwright, $\dagger$ Salt Lake City, Utah. ASCI

\section{IMMUNOLOGY AND CONNECTIVE TISSUE}

$$
\text { Sunday, May 1, } 1966
$$

\section{Afternoon Session}

\section{2:30 p.m. West Room, Haddon Hall \\ Chairman: Dr. Robert A. Good}

1. Radioimmunoassay of Angiotensin, Bradykinin, and $\alpha$-Melanocyte Stimulating Hormone. T. Goodfriend, $\ddagger$ G. T. Ross, § and D. S. Schalch, $\ddagger$ Rochester, N. Y. AFCR

2. Cyclophosphamide Inhibition of an Autoimmune Disease, Allergic Encephalomyelitis in Rats. P. Y. Paterson,* E. W. Gerner, F. M. Steele, and M. A. Hanson, Chicago, Ill., and New York, N. Y. ASCI

3. The Role of Antigen Dose in Acriflavine-induced Immunologic Paralysis. S. C. KRAFT, $\ddagger$ J. S. SAm UELson, $\ddagger$ and R. S. FARR,§ La Jolla, Calif. AFCR

4. Localization of Antigens within Subgroups of Lysosomes. G. WeIsSMANN $\ddagger$ and J. W. Uhr, $\ddagger$ New York, N. Y. AFCR

5. Immunoglobulin (Gamma Globulin) Formation by Human Cells in Continuous Culture. I. Finegold, A. S. Rabson, and J. L. Fahey,* Bethesda, Md. ASCI

6. Gamma Globulin Synthesis by Lymphocytes from Normal and Agammaglobulinemic Individuals. S. R. Cooperband, F. S. Rosen, S. Kibrick, and C. A. Janeway,* Boston, Mass. ASCI

7. Immunoglobulin and Antibody Production by Human Peripheral Lymphocytes In Vitro. K. HIRSCH HORN * and C. S. Ripps, New York, N. Y. ASCI

8. The Relationship between Intestinal Plasma Cells and Serum Immunoglobulin A (IgA) in Man. S. EIDELman, S. D. Davis, D. Lagunoff, and C. E. Rubin,* Seattle, Wash. ASCI

9. The Relation of Differential Cellular Recognition of Antigen-Antibody Complexes to Species Origin of Antibody. R. Patterson * and I. M. Suszko, Chicago, Ill. ASCI 


\section{INFECTIOUS DISEASES}

Sunday, May 1, 1966

\section{Afternoon Session \\ 2:30 p.m. Viking Room, Haddon Hall \\ Chairman: Dr. Gene H. Stollerman}

1. Inhibition of the Bactericidal Activity of Alveolar Macrophages by Cigarette Smoke. G. M. GreEN and D. Carolin, Boston, Mass. (introduced by E. H. Kass $\dagger$ ). ASCI

2. The Relationship between Amphotericin B Action and Membrane Sterols. D. S. FeIngold, Boston, Mass. (introduced by A. S. Freedberg $\dagger$ ). ASCI

3. The Effects of Amantadine $\mathrm{HCl}$ on Experimental Human Influenza. G. SchIFf, $\ddagger$ S. Bloomfield, $\ddagger$ and T. GaffNey, $\ddagger$ Cincinnati, Ohio. AFCR

4. Lysostaphin: An Enzymatic Approach to the Therapy of Experimental Staphylococcal Infections. W. Schaffner, $\ddagger$ M. A. Melly, $\ddagger$ and M. G. Koenig, $\ddagger$ Nashville, Tenn. AFCR

5. Antibacterial Activity of the Urinary Bladder. C. G. CoBbS and D. KAyE, New York, N. Y. (introduced by E. W. Hook *). ASCI

6. Effect of Vesical Mucosa on Bacterial Growth. G. Mulholland, E. Foster, J. Gillenwater, $\ddagger$ and A. PAQUin, Charlottesville, Va. AFCR

7. Immunologic Tolerance Associated with Congenital Murine Reovirus Infections. M. M. Carruthers, A. A. Hashimi, and A. M. Lerner, Detroit, Mich. (introduced by C. Harford $\dagger$ ). ASCI

8. Recovery of Thymectomized Mice from Herpes Simplex Skin Infection. I. Schultz, $\ddagger$ St. Louis, Mo. AFCR

9. The Role of Endotoxin during Typhoid Fever and Tularemia in Man. S. E. Greisman,* R. B. HoRnick, W. E. Woodward, and T. E. Woodward, $\dagger$ Baltimore, Md. ASCI

\section{METABOLISM}

Sunday, May 1, 1966

\section{Afternoon Session \\ 2:30 p.m. Music Room, Chalfonte \\ Chairman: Dr. Leonard L. Madison}

1. Metabolic and Immunologic Studies in Addison's Disease. K. D. Wuepper, L. C. WegrenkA, and H. H. Fudenberg, $\ddagger$ San Francisco, Calif. AFCR

2. Brain Metabolism during Starvation. O. E. Owen, J. M. Sullivan, $\ddagger$ and G. F. CahIll, JR., $\ddagger$ Boston, Mass. AFCR

3. Mechanisms for the Regulation of Serum Insulin Levels by Catecholamines in Man. D. Porte, JR., Seattle, Wash. (introduced by R. H. Williams $\dagger$ ). ASCI
4. The Acceleration of Healing by Oral Zinc Therapy. W. J. Pories, $\ddagger$ D. E. Burget, $\ddagger$ J. H. Henzel, J. L. Smith, and W. H. Strain, Dayton, Ohio, and Rochester, N. Y. AFCR

5. Glycogen Synthetase Activity in Human Leucocytes. H. E. Williams $\ddagger$ and U. I. Lundholm, San Francisco, Calif. AFCR

6. Action of Diazoxide on Glucose Metabolism and Plasma Lipids. S. S. Sanbar, Toronto, Canada (introduced by J. C. Laidlaw $\ddagger$ ). AFCR

7. Studies of Extracellular and Tissue Fatty Acid Pools and Glucose Metabolism in Striated Muscle. G. Schonfeld and D. M. KIPNIS,* St. Louis, Mo. ASCI

8. The Inhibition of Bone Resorption by Thyrocalcitonin. H. F. Kohler and M. M. Pechet, $\dagger$ Boston, Mass. ASCI

9. Early Effects of Parathyroid Hormone on Bone in Tissue Culture. L. G. RaIsz * and I. Niemann, Rochester, N. Y. ASCI

\section{NEOPLASTIC DISEASES}

Sunday, May 1, 1966

\section{Afternoon Session}

\section{2:30 p.m. Solarium, Haddon Hall}

Chairman: Dr. Nathaniel I. Berlin

1. Prognosis by Computer: Based on Storage and Retrieval of Data for 5-Year Clinical Course of 691 Cases of Lung Cancer. A. R. Feinstein and N. Koss, New Haven, Conn. (introduced by J. W. Hollingsworth *). ASCI

2. Three Technics for Obtaining Tumor Karyotypes. S. M. Kotler and H. A. LubS, JR., $\ddagger$ New Haven, Conn. AFCR

3. Reticuloendothelial System (RES) Function in Hodgkin's Disease. J. N. Sheagren, J. B. Block, $\ddagger$ and S. M. WolfF, $\ddagger$ Bethesda, Md. AFCR

4. The Metabolic Effects Caused by the Administration of Bovine Pancreatic Ribonuclease to Patients with Cancer. R. D. Leeper and A. Haymovitz, New York, N. Y. (introduced by J. Burchenal $\dagger$ ). ASCI

5. The Effect of Immune Whole Spleen Transplants on Homograft Rejection in Tumor-bearing Mice. P. G. RIGBy, $\ddagger$ Omaha, Neb. AFCR

6. Serum Hyperviscosity and Metabolic Acidosis Due to Circulating Hyaluronic Acid. T. B. Tomasi, JR.,* W. VAN B. Robertson, R. NAEye, and M. ReichLIN, Buffalo, N. Y. ASCI

7. Urinary Excretion of a Cationic Protein with Lysozyme (Muramidase) Properties in Monocytic Leukemia. E. F. Osserman * and D. P. LAwLor, New York, N. Y. ASCI

8. Drug Transport by Human Blood Cell Types. D. KESSEL, $\ddagger$ Boston, Mass. AFCR

9. Neutrophil Malfunction in Plasma Cell Dyscrasias. R. Penny and D. A. G. Galton, London, England (introduced by E. F. Osserman $\ddagger$ ). AFCR 


\section{PULMONARY}

Sunday, May 1, 1966

Afternoon Session

2:30 p.m. Pennsylvania Room III, Haddon Hall

\section{Chairman: Dr. John W. Severinghaus}

1. Effects of Small Amounts of Carboxyhemoglobin on Oxygen Transport. S. M. Ayres and S. Giannelli, JR., New York, N. Y. (introduced by D. B. Louria *). ASCI

2. Distribution of Blood Flow to the Maternal and Fetal Portions of the Sheep Placenta Using MacroAggregates. G. G. Power, L. D. Longo, H. N. Wagner, Jr.,* D. E. KuHL, and R. E. Forster, $\dagger$ Philadelphia, Pa., and Baltimore, Md. ASCI

3. Paradoxical Effects of Microemboli and of Asystole on Pulmonary Diffusing Capacity in Dogs. W. J. DALY, Indianapolis, Ind. (introduced by J. C. Ross*). ASCI

4. Effect of Acute Hypoxia on the Pulmonary Capillary Bed. R. J. Puy, P. Berg, B. Felipe, E. Rincon, R. W. Hyde, $\ddagger$ and A. B. DuBors, Philadelphia, Pa. AFCR

5. Effect of Chronic Oxygen Administration on the Pulmonary Circulation in Chronic Airway Obstruction. H. J. Beckwitr, Denver, Colo. (introduced by C. A. Chidsey $\ddagger$ ). AFCR

6. Effect of Blood Fluidity on Flow in Pulmonary Capillaries. K. H. KILBURN $\ddagger$ and L. HART, Durham, N. C. AFCR

7. Selective CNS Lactic Acidosis in Response to Hypocapnia. F. PluM * and J. B. Posner, New York, N. Y. ASCI

8. Respiratory Compensation in Chronic Metabolic Acidosis of Uremia. L. W. HeNDERSON, $\ddagger$ B. Rodriguez, R. W. Hyde, $\dagger$ and L. W. Bluemle, JR., $\ddagger$ Philadelphia, Pa. AFCR

9. The Influence of Hypoxemia on the Defense of $\mathrm{pH}$ in Chronic Hypercapnia. D. Z. Levine, D. C. SAPIR, and W. B. Schwartz,* Boston, Mass. ASCI

\section{RENAL AND ELECTROLYTES}

Sunday, May 1, 1966

Afternoon Session

2:30 p.m. Casino Theater, Steel Pier

Chairman: Dr. William B. Schwartz

1. Demonstration and Partial Characterization of a H'moral Renal Growth Factor. L. M. Lowenstein $\ddagger$ and E. L. Lozner, Boston, Mass. AFCR

2. A Comparison of the Antihypertensive Potency of Kidneys from One Strain of Rats Susceptible to Salt Hypertension and Kidneys from Another Strain Resistant to It. L. Tobian,* K. Coffee, P. McCrea, and L. DAHL, Minneapolis, Minn., and Upton, N. Y. ASCI

3. On the Mechanism of Proteinuria in Non-glomerular Renal Disease. S. W. Shankel, A. M. Robson, B. V. JAgER, $\S$ and N. S. BrICKer, + St. Louis, Mo. AFCR

4. The Role of Phosphorylase and Phosphofructokinase in the Regulation of Glycolysis in Toad Bladder. J. S. Handler * and J. Rogulski, Bethesda, Md. ASCI

5. Characteristics of Hydrogen Ion Transport in Urinary Bladder of the Turtle. P. R. Steinmetz and H. S. Frazier,* New York, N. Y., and Boston, Mass. ASCI

6. Effect of Extracellular Fluid (ECF) Volume Expansion, $\mathrm{K}^{+}$Deficiency, and $\mathrm{pCO}_{2}$ on Bicarbonate Reabsorption in the Rat Kidney. R. KunAU, A. FrICK, F. C. Rector, JR., $\ddagger$ and D. W. Seldin, $\$$ Dallas, Texas. AFCR

7. The Effect of Expansion of the Extracellular Space on the Rate of Urinary Calcium Excretion. W. B. Blythe, $\ddagger$ H. L. Gitelman, and L. G. Welt, $\S$ Chapel Hill, N. C. AFCR

8. An Extrarenal Mechanism of Tolerance to Acute Potassium Loads. E. AlexANDER and N. G. LevinSKY,* Boston, Mass. ASCI

9. Mineralocorticoid Effects on Renal and Adrenal Function in Hypertension. P. E. Slaton $\ddagger$ and E. G. Biglieri, $\ddagger$ San Francisco, Calif. AFCR 


\section{THE AMERICAN FEDERATION FOR CLINICAL RESEARCH TWENTY-THIRD ANNUAL MEETING}

\section{GENERAL SESSION}

Sunday, May 1, 1966 8:50 a.m. Pennsylvania Room,
Haddon Hall

(The time for the presentation of each paper will be limited to 12 minutes.)

Chairman: Dr. Richard J. Havel

1. Isovaleric Acidemia : An Inherited Defect of Leucine Metabolism. M. A. Budd, K. Tanaka, M. L. EFron, L. B. Holmes, and K. J. Isselbacher, $\ddagger$ Boston, Mass.

2. Genetic Obesity in Rats: A Fat Storage Disease. G. A. Bray $\ddagger$ and D. J. Galton, Boston, Mass.

3. A Correlative Electron Microscopic and Lipid Biochemical Study on Evolving Experimental Xanthoma. F. PARKer $\ddagger$ and G. OdLAND, Seattle, Wash.

4. Free Sugars in Alloxan Diabetic Rat Nerve. M. A. Stewart, $\ddagger$ W. R. Sherman, and S. Anthony, St. Louis, Mo.

5. Independent Regulation of Arginine Vasopressin (AVP) and Oxytocin (OT) Secretion in Man. A. B. J. Ahmed, B. C. George, and J. F. Dingman,§ Boston, Mass.

6. Hyperparathyroidism Complicating Renal Homotransplantation. D. A. McIntosh and J. J. McPhaul, JR., $\ddagger$ San Antonio, Texas.

The President's Address: Dr. Richard J. Havel

\section{Intermission}

7. Water and Solute Absorption in Sprue. J. S. Fordtran $\ddagger$ and F. C. Rector, $\ddagger$ Dallas, Texas.

8. Erythroid Cell Development in Fetal Mice: Biochemical and Ultrastructural Analysis. J. S. KovAcH, E. S. Russell, and P. A. MARKs, $\ddagger$ New York, N. Y., and Bar Harbor, Me.

9. Mechanism of "Target Cell" Formation in Jaundice. R. A. CoOper and J. H. JANdL $\ddagger$ Boston, Mass.

10. A Protective Role for Rheumatoid Factor. J. S. Davis $\ddagger$ and W. W. Gougr, Charlottesville, Va.

11. Depletion of Coagulation Factors in Drug Resistant Plasmodium Falciparum Malaria. L. H. Dennis, $\ddagger$ J. W. Eichelberger, $\ddagger$ and M. E. Conrad, $\ddagger$ Washington, D. C.

12. The Mechanical Performance of the Amine-depleted Isolated Heart. C. Bariso, H. Fukusumi, J. Holmes, N. Fowler, $\ddagger$ and T. GafFNey, $\ddagger$ Cincinnati, Ohio.
13. Physiologic Evaluation of Internal Mammary Artery Pedicle Implantation (IMAPI) in Man. J. M. Sullivan, $\ddagger$ M. V. Herman, W. J. Taylor, and R. Gorlin, $\ddagger$ Boston, Mass.

\section{EVENING SECTIONAL MEETINGS CARDIOVASCULAR}

\author{
Sunday, May 1, 1966 \\ Evening Session \\ 7:30 p.m. Pennsylvania Room II, \\ Haddon Hall
}

Chairman: Dr. Jere H. Mitchell

1. Cardiovascular Responses to Carbon Dioxide before and after Beta Adrenergic Blockade. M. G. WENDLING, J. W. Ecrstein,§ F. M. Abboud, $\ddagger$ and W. K. Hamilton,§ Iowa City, Iowa.

2. A Simplified Means for Detecting Adrenergic Influences on the Human Left Ventricle. W. S. HARRIs, $\ddagger$ C. D. Schoenfeld, $\ddagger$ and A. M. Weissler, $\ddagger$ Columbus, Ohio.

3. Inotropic Response to Atrial Fibrillation in Dogs. R. H. Martin, $\ddagger$ S. T. Lim, and R. L. VAN Citters, $\ddagger$ Seattle, Wash.

4. A Defect in the Accumulation of Tritiated Norepinephrine (NE) in Hypertensive Rats. J. DE CHAMplain, L. Krakoff, and J. Axelrod, Bethesda, Md. (introduced by R. J. Wurtman $\ddagger$ ).

5. Increase of $\mathrm{Myocardial} \mathrm{O}_{2}$ Consumption and Decrease of Myocardial Efficiency Produced by Digitalis. J. W. Covell, E. Braunwald, $\ddagger$ J. Ross, Jr., $\ddagger$ and E. $H$. Sonnenblick, $\ddagger$ Bethesda, Md.

6. Metabolism of Digitoxin in Man. C. N. LEACH, JR., R. E. Peterson,§ and D. S. Lukas,§ New York, N. Y.

\section{DERMATOLOGY}

Sunday, May 1, 1966

Evening Session

\section{7:30 p.m. Terrace Room, Colton Manor}

\section{Chairman: Dr. Richard L. Dobson}

1. Warfarin Antagonism by Griseofulvin. P. M. Catalano $\$$ and S. I. Cullen, $\$$ Miami, Fla.

2. Electron Microscopic Observations Relating Fabry's Disease to Other Sphingolipidoses. R. SAgebiel and F. PARKer, $\ddagger$ Seattle, Wash. 
3. Fatty Acid Oxidation in Skin. J. H. Herndon, JR., and J. S. McGuire, $\ddagger$ New Haven, Conn.

4. Components of the Response of Sebaceous Glands to Testosterone. R. K. Freinkel, Boston, Mass. (introduced by N. Freinkel $\ddagger$ ).

5. Mechanisms Involved in Contact Photoallergic Reactions to Salicylanilides and Related Compounds. $\mathrm{L}$. C. Harber, $\ddagger$ H. Harris, and R. L. BaER, New York, N. Y.

6. Ultraviolet Induced Kinin Formation in Normal Human Skin. J. H. EPstein $\ddagger$ and R. K. WinkelMANN, $\ddagger$ San Francisco, Calif., and Rochester, Minn.

\section{ENDOCRINOLOGY}

Sunday, May 1, 1966

Evening Session

\section{7:30 p.m. Carolina Room, Chalfonte}

\section{Chairman: Dr. J. Thomas Dowling}

1. The Relationship of Plasma Thyrotropin to Plasma Free and Total Thyroxine Concentration. R. D. UTIger $\ddagger$ and S. REICHLIN, $\ddagger$ St. Louis, Mo., and Rochester, N. Y.

2. Basal Insulin Turnover. L. VINNICK and N. FrEINKEL, $\ddagger$ Boston, Mass.

3. Lipolytic Action of Human Placental Lactogen on Isolated Fat Cells. J. R. Turtle, G. Litrleton, and D. M. KIPNIs, $\ddagger$ St. Louis, Mo.

4. Mode of Action of Thyrocalcitonin. J. L. $\mathrm{H}$. O'Riordan and G. D. Aurbach, $\$$ Bethesda, Md.

5. Coupled Oxidative Phosphorylation in Muscle of Thyrotoxic Patients. W. W. Stocker, F. J. Samaha, $\ddagger$ and L. J. DeGroot $\ddagger$ Boston, Mass.

6. Dehydroepiandrosterone-Sulfate: Biologic Activity in Man. W. D. Drucker, $\ddagger$ J. M. Blumberg, and R. David, New York, N. Y.

\section{GASTROENTEROLOGY}

Sunday, May 1, 1966

Evening Session

7:30 p.m. Rutland Room, Haddon Hall

Chairman: Dr. Robert M. Donaldson, Jr.

1. Antibodies to Intrinsic Factor in Gastric Juice of Pernicious Anemia Patients. J. M. FISHER $\ddagger$ and K. B. Taylor,§ Palo Alto, Calif.

2. Stability of the Normal Human Intestinal Microflora. P. Lerner, S. Gorbach, L. Nahas, and L. WeinSTEIN, $\ddagger$ Boston, Mass.

3. Cholesterol Absorption from the Small Intestine: Perfusion Studies with a Micellar Solution in Man. W. J. Simmonds, E. Theodor, and A. F. Hofmann, $\ddagger$ New York, N. Y.

4. Effect of Diet upon Intestinal Disaccharidases and Disaccharide Absorption. J. J. Deren, $\ddagger$ S. A. BroItMAN, $\ddagger$ and N. ZAMCHECK, $\S$ Boston, Mass.
5. The Incorporation of $\mathrm{H}^{3}$-Leucine into Intestinal $\mathrm{Mu}$ cosal Protein in Protein-deprived Rats. H. HIRSCHFIELD and F. KeRN, JR.,§ Denver, Colo.

6. Liver Growth Induced by Butylated Hydroxy-Toluene. R. KerR, A. Lefevre, B. Lane, and C. S. Lieber, $\ddagger$ New York, N. Y.

\section{HEMATOLOGY}

Sunday, May 1, 1966

Evening Session

7:30 p.m. Vernon Room, Haddon Hall

Chairman: Dr. Ernest Beutler

1. Leukocidal Factor in Leukemic Plasma. J. H. LAPIN, R. H. LAPIN, and A. Horonick, Bronx, N. Y., and Ann Arbor, Mich. (introduced by H. S. Spencer $\ddagger$ ).

2. The Placental Barrier to Leukemia. J. R. RUBINI $\ddagger$ and S. Brickson, $\ddagger$ Miami, Fla.

3. Absorption of Hemoglobin Iron. E. B. Brown, $\ddagger$ Y.-F. Hwang, and S. Nicol, St. Louis, Mo.

4. Selective Advantage of Reticulocytes in Pyruvate Kinase (PK) Deficiency. A. S. KeItT and J. H. JANDL $\ddagger$ Boston, Mass.

5. Inhibition of the Stem Cell Action of Erythropoietin by Estradiol. J. H. JePSON and L. Lowenstein, Montreal, Canada (introduced by N. K. M. de Leeuw $\ddagger$ ).

6. Preparation and Clinical Evaluation of Cyro-Factor VIII. L. R. Simson, H. A. Oberman, and J. A. Penner, $\ddagger$ Ann Arbor, Mich.

\section{IMMUNOLOGY AND CONNECTIVE TISSUE}

\section{Sunday, May 1, 1966 \\ Evening Session \\ Chairman: Dr. H. Hugh Fudenberg}

7:30 p.m. West Room, Haddon Hall

1. Human Immunoglobulin D (IgD) Metabolism. G. N. Rogentine, JR., D. S. Rowe, J. 'Bradley, T. A. Waldmann, $\ddagger$ and J. L. FAhey, $\ddagger$ Bethesda, Md.

2. Essential Cold Precipitable Kappa Type IgG Associated with Cold Urticaria. J. J. CostanzI $\ddagger$ and C. A. Cotman, JR., $\ddagger$ San Antonio, Texas.

3. The Presence of Complement $\left(C^{\prime}\right)$ Components in Properdin Preparations. D. Rosenblum and $\mathrm{S}$. YACH NIN, $\ddagger$ Chicago, IIl.

4. Increase of Normal Cord over Maternal IgG: Evidence for an Active Rather than Passive IgG Transport. P. F. KoHLER and R. S. FARR,§ La Jolla, Calif.

5. Dynamic Relationship between Antinuclear Factor (ANF) and Biologic False Positive (BFP) Reaction. H. Nagaya $\ddagger$ and H. O. Sieker, $\ddagger$ Durham, N. C.

6. Structural Studies of Human $\gamma$ Myeloma $H$ Chains of Different Antigenic Subgroups and Genetic Specifici- 
ties. H. H. Fudenberg, $\ddagger$ B. Frangione, E. C. Franklin, $\ddagger$ and M. Koshland, San Francisco, Calif., and New York, N. Y.

\section{INFECTIOUS DISEASES}

\author{
Sunday, May 1, 1966 \\ Evening Session \\ 7:30 p.m. Viking Room, Haddon Hall \\ Chairman: Dr. Calvin M. Kunin
}

1. Antibacterial Activity of the Urethral Mucosa. O. KUNII and E. H. KASs, $\S$ Boston, Mass.

2. The Effect of $\mathrm{pH}$, Glucose, and Bacteria on Human PMN Migration. R. Bryant, $\ddagger$ M. VanWay, and D. Rogers, $\ddagger$ Nashville, Tenn.

3. Release of White Cell Lysosomal Enzymes by Antibodies against Staphylococcal Teichoic Acids. R. R. Martin, J. G. Crowder, and A. White, $\ddagger$ Augusta, Ga.

4. Pneumococcal Pneumonia with Leucopenia-the Role of Folic Acid. R. W. Burmeister, $\ddagger$ B. J. Dreiling, G. Bazzano, and G. O. Brown, Jr., $\ddagger$ St. Louis, Mo.

5. Immunoglobulin Response in Patients with Infections of the Urinary Tract. K. L. Vosti $\ddagger$ and J. S. REMInGton, $\ddagger$ Palo Alto, Calif.

6. Separation of Enhancing Effect of DEAE-Dextran on Infectious RNA from Its Effect on Progeny Virus. J. S. Pagano, $\ddagger$ Chapel Hill, N. C. (introduced by L. Welt $\ddagger$ ).

\section{METABOLISM}

Sunday, May 1, 1966

Evening Session

\section{7:30 p.m. Music Room, Chalfonte}

\section{Chairman: Dr. David M. Kipnis}

1. A Kinetic Model for Calcium Absorption. S. J. Birge, JR., W. A. Peck, $\ddagger$ and M. Berman, Bethesda, Md.

2. Estimation of Urate Secretion in Health and Disease. T. H. Steele and R. E. Rieselbach, $\ddagger$ Madison, Wis.

3. Studies of the Mechanism by Which Phosphate Infusion Lowers Serum Calcium. L. A. Hebert, J. Lemann, Jr., $\ddagger$ J. R. Petersen, $\ddagger$ and E. J. Lennon, $\ddagger$ Milwaukee, Wis.

4. Basal Insulin Turnover. L. VinNICK and N. FreINKEL, $¥$ Boston, Mass.

5. Effect of $\left[\mathrm{H}^{+}\right]$on Renal and Hepatic Gluconeogenesis in Diabetes and Starvation. D. E. KAMM $\ddagger$ and G. F. CAHILl, JR., $\ddagger$ Boston, Mass.

6. Transfer of Cholesterol from Intestinal Wall to Lymph. R. T. Reinke and J. D. Wilson, $\ddagger$ Dallas. Texas.

\section{NEOPLASTIC DISEASES}

Sunday, May 1, 1966

Evening Session

7:30 p.m. Solarium, Haddon Hall

Chairman: Dr. Emil J. Freireich

1. Divergent Behaviour of Normal and Pathological Lymphocytes Evoked by $B_{6}$ Deficiency and 4-Deoxypyridoxine. S. Gailani and J. F. Holland, $\ddagger$ Buffalo, N. Y.

2. Occurrence of Elevated Blood and Urine Histamine in Myeloproliferative Disorders. H. S. GILBERT, $\ddagger$ S. KRAUSS, $\ddagger$ R. R. P. WARNER, $\ddagger$ and L. R. WASSERMAN,§ New York, N. Y.

3. Inhibition of Effects of Murine Leukemogenic Viruses in Mice by Extracts of M. Mercenaria. J. R. JUDGE, Cleveland, Ohio (introduced by A. D. Heggie $\ddagger$ ).

4. Clinical and Laboratory Evaluation of Patients with Hodgkin's Disease Complicated by Bacterial Infection. J. K. Cunningham and J. E. Ultmann, $\ddagger$ New York, N. Y.

5. Mycoplasma from Human Leukemia Tissue. J. S. Horoszewicz $\ddagger$ and J. T. Grace, JR., Buffalo, N. Y.

6. Metabolism of S-Adenosylmethionine in Chronic Myelogenous Leukemia. W. BELL, P. P. CARBONE, $\ddagger$ and $\mathrm{H}$. Weissbacr, Bethesda, Md.

\section{PATIENT CARE}

Sunday, May 1, 1966

Evening Session

7:30 p.m. Garden Room, Haddon Hall

Chairman: Dr. John H. Knowles

1. Determinants of the Public's Perception of Medical Care. D. Apostle and F. Oder, Rochester, N. Y. (introduced by R. L. Berg $\S$ ).

2. A Patient-centered Technique for Fostering the Continuing Education of General Practitioners by the Teaching Hospital. K. WeInstein and P. Torrens, New York, N. Y. (introduced by J. F. Bertles $\ddagger$ ).

3. Predicting the Quality of Patient Care in Hospitals. J. C. Denton, A. B. Ford, $\ddagger$ R. E. Liske, and R. S. OrT, Cleveland, Ohio.

4. Outpatient Care-Diagnosis and Prognosis. M. B. Sussman, E. Caplan, M. Haug, and M. Lamport, Cleveland, Ohio (introduced by J. E. Walker $\ddagger$ ).

5. Variations between Emergency Room Populations of Different Hospitals. P. R. TorRens and D. G. YedvAB, New York, N. Y. (introduced by T. B. Van Itallie $\ddagger)$.

6. Analysis of Patterns of Hospital Admission and Care Using Computer Retrieval Techniques. V. W. SmeL, $\ddagger$ R. A. Greenes, G. O. BarnetT, $\ddagger$ and J. H. Knowles, $\ddagger$ Boston, Mass. 


\section{PULMONARY}

Sunday, May 1, 1966

Evening Session

7:30 p.m. Pennsylvania Room III, Haddon Hall

\section{Chairman: Dr. John F. Murray}

1. Selective Arteriography and Lung Scanning in the Differential Diagnosis of Pulmonary Thromboembolism. H. L. Fred, $\ddagger$ D. A. Gonzalez, R. W. Lockhart, C. A. Peabody, and J. K. Alexander, $\S$ Houston, Texas.

2. Pulmonary Scanning DLco and Emphysema. B. Weiner, D. E. Jenkins, JR., and P. C. Johnson, JR.,§ Houston, Texas.

3. Failure of Circulatory Adjustment to Ventilation, a Cause of Severe Hypoxia and Cor Pulmonale. G. EMmanuel, $\ddagger$ Brooklyn, N. Y.

4. Distribution of Function in Normal and Transplanted Lungs in Dogs. D. Joussaet-STRIEDER, $\neq \mathrm{H}$. KaZEMI, $\ddagger$ and B. A. BARNes, $\ddagger$ Boston, Mass.

5. The "Anti-Atelectasis" Function of Pulmonary Vascular Perfusion. S. Gianelli, JR. $\$$ and S. M. Ayres, $\ddagger$ New York, N. Y.

6. Comparison of Respiratory Elastances in Relaxed and Paralyzed States in Normal and Diseased Men. P. von Lith, R. D. Thompson, F. N. Johnson, and J. T. Sharp, $\ddagger$ Hines, Ill.

\section{RENAL AND ELECTROLYTES}

\author{
Sunday, May 1, 1966
}

Evening Session

\section{7:30 p.m. Casino Theatre, Steel Pier}

Chairman: Dr. Roy H. Maffly

1. Treatment of Chronic Proliferative Glomerulonephritis with Heparin. D. ShIREs, $\ddagger$ A. Holcomb, $\neq$ J. CAdE, $\ddagger$ and D. Levin, $\ddagger$ Gainesville, Fla.

2. The Influence of Ethacrynic Acid on Erythrocyte ATPase. E. K. M. Smith, A. Czerwinski, H. J. Gitelman, and L. G. Welt, $\S$ Chapel Hill, N. C.

3. An In Vivo and In Vitro Appraisal of the Urinary Concentrating Mechanism in the Kaliopenic Rat. K. D. Gardner, JR.,\$ Palo Alto, Calif.

4. Influence of Medullary Circulation on the Osmotic Gradient of the Kidney. S. CARRIÈre, $\ddagger$ Montreal, Canada.

5. Biologically Effective Immunization to Angiotensin. T. U. L. BIBer and D. E. Oken, $\ddagger$ Boston, Mass.

6. Renal Venous Renin (RVR) in Evaluation of Renovascular Hypertension. A. E. Frrz, $\ddagger$ Iowa City, Iowa. 


\section{LISTING OF TECHNICAL EXHIBITS AT THE FIFTY-EIGHTH ANNUAL MEETING OF THE AMERICAN SOCIETY FOR CLINICAL INVESTIGATION, INC., 1966}

\begin{tabular}{|c|c|c|c|}
\hline & Booth no. & & Booth no. \\
\hline ABbott LaboRatories & D5 & LEA \& FEBIGER & E4 \\
\hline ACAdEMIC Press, Inc. & K4 & E. LEITZ, INC.* & G4 \\
\hline AdVANCED INSTRUMents, InC.* & J1 & Lexington Instruments Sales Corp. & I1 \\
\hline American Elsevier Publishing Co., Inc. & J8 & J. B. Lippincott Co. & D1 \\
\hline AMERICAN InSTRUMent Co., Inc. & K2 & LitTLE, BRown \& Co. & A1 \\
\hline American Optical Co. & E6 \& E7 & THE London Co.* & E3 \\
\hline H. ReEve Angel \& Co., Inc. & G8 & The Macmillan Co.* & F7 \\
\hline ApPleton-Century-Crofts & H8 & McGraw-Hill Book Co., Blakiston & \\
\hline BAIRD-Atomic, Inc. & F8 & Drv.* & H1 \\
\hline Becton, Dickinson \& Co. & $\mathrm{J} 3$ & The C. V. Mosby Co. & $\mathrm{I} 2$ \\
\hline BOEHRINGER MANNHEIM CoRP. & G6 \& G7 & New England Nuclear Corp. & C8 \\
\hline BROOKLINE INSTRUMENT Co., INC.* & A9 \& A10 & NuClear-Chicago Corp.* & $\mathrm{C} 1 \& \mathrm{C} 2$ \\
\hline BUTTERWORTH INC. & L7 & Nuclear Consultants Corp.* & $\mathrm{J} 2$ \\
\hline CAMBRIDGE INSTRUMENT Co., Inc. & K1 & Oxford UnIVERSITY Press, Inc. & A4 \\
\hline CAMBRIDGE NUClear CoRp.* & L6 & PaCkard Instrument Co., Inc.* & L1 \& L2 \\
\hline WarRen E. Collins, Inc. & $\mathrm{H} 2$ & PERKIN-ELMER CoRP.* & D6 \& D7 \\
\hline Coulter Electronics Sales Co.* & D4 & Pharmacia Fine Chemicals Inc. & A2 \\
\hline F. A. Davis Co. & J4 & PhIPps \& BIRd, INC.* & C7 \\
\hline $\begin{array}{l}\text { Department of Health, Education, and } \\
\text { Welfare, U. S. Public Health SERv- } \\
\text { ICE, Div. of Chronic Diseases, Heart }\end{array}$ & & $\begin{array}{l}\text { Picker NuClear Division, Picker X- } \\
\text { Ray Corp.* } \\
\text { Precision Systems }\end{array}$ & $\begin{array}{l}\mathrm{G} 1, \mathrm{G} 2, \& \mathrm{G} 3 \\
\mathrm{~L} 4\end{array}$ \\
\hline Disease Control Program & D8 & QUinton Instrument Co. & G5 \\
\hline Electro-Catheter Corp. & F6 & Sanborn Division, Hewlett-Packard & \\
\hline ELECTRODYNE Co., Inc. & & Co.* & C6 \\
\hline ELECTRONICS FOR MEDICINE, INC. & A7 \& A8 & W. B. SAUnders Co. & B6 \& B7 \\
\hline ExtraCoRPoReal \& Medical Spectalties & & SaVANT Instruments, Inc. & F4 \\
\hline Co., INc.* & I7 & SLEE International Inc. & E5 \\
\hline Fisher Scientific Co. & A5 \& A6 & Smith Kitne Instrument Co. & L5 \\
\hline Fiske Associates, Inc.* & F5 & SpRINGER-VerLag New York, Inc. & L8 \\
\hline GILFORD INSTRUMENT LABORATORIES, INC.* & F1 & E. R. SQuibB \& Sons* & D3 \\
\hline Grune \& Stratton, Inc. & B1 & TECA CoRp. & B8 \\
\hline Gulton Medical Instruments & I8 & TeCHNicon Instruments CoRp. & A3 \\
\hline Hoeber Medical Division, Harper \& & & Arthur H. Thomas Co. & E8 \\
\hline Row & H7 & UNITRON INSTRUMENT Co.* & $\mathrm{K} 5$ \& K6 \\
\hline Hoechst Pharmaceuticals, INC. & $\mathrm{J} 5$ & ThE Waters Co.* & D2 \\
\hline THE Holter Co. & I6 & The Williams \& Wilkins Co. & L3 \\
\hline INSTRUMENTATION Associates, INC.* & E1 \& E2 & Worthington Biochemical Corp.* & F2 \\
\hline INSTRUMENTATION LABORATORY INC.* & H6 & Year Book Medical Publishers, Inc.* & F3 \\
\hline $\begin{array}{l}\text { InTERContinental Medical Book Corp. } \\
\text { JARRELI-A SB Co. }\end{array}$ & $\mathrm{B} 2$ 11 \& $\mathrm{A} 12$ & The Coca-Cola Co.* & Special Area \\
\hline LKB INSTRUMENTS, INC. & $\mathrm{K} 3$ & ertisement in this issue. & \\
\hline
\end{tabular}

